\title{
THE COLONIZATION OF AFRICA
}

ONE of the most fascinating and fruitful chapters in the history of civilization is the permanent grafting of one national stock upon another, living under totally different climatic and health conditions, and under totally different traditions and environment.

We often debate the same question in another form; for example, when we discuss why the Red Indian and many other wild races have disappeared before the white man. Or, why many wild animals and plants cannot be acclimatized in Europe in spite of artificial conditions of temperature, \&c. Or, why, for example, it is not always possible to graft one branch upon another in plant life

The solution of these and allied problems is not an easy one, and reasons for the admitted failure to colonize West Africa in the broadest sense are equally complex.

We can treat this subject under four headings :-

(1) Climatic conditions.

(2) Health conditions.

(3) Tradition.

(4) Environment.

All I can hope to do in this short note is to draw from the records of past and present experience in the history of colonization in other parts of the world, sufficient matter to throw some light upon the statement, so often made with a shrug of the shoulders, that "Africa is not a white man's country."

To commence with, when the New World was discovered by the Conquistadores of Spain, the soldiers, priests, and merchant adventurers found themselves in a continent already peopled by the descendants of the Aztecs and Toltecs, with laws and traditions behind them quite as ancient as their own. From the outset the invaders and invaded were men fairly equally matched. The American continent had 
reared the native inhabitant to a high degree of civilization, and no doubt the invaders argued that it could do the same for them, and so the Spaniards settled, traded, and intermingled with the natives, and the result is shewn by the immense Spanish-Indian populations which form the races of Central and South America to-day. Thus, to this day in Hayti I am informed by residents of long experience that the aristocracy, chief merchants, artists, sculptors, and statesmen are those known as the "peaux-jaunes," the descendants of the Spanish-Indians. On the other hand, the labouring classes, i.e., the hewers of wood and drawers of water, are the "peaux-noires," the imported negro race. To-day, therefore, two people of different origin exist in the little Island of Hayti, "peaux-jaunes" and "peaux-noires," both as distinctive as the north and south poles.

Again, when the Romans invaded England they met with races who, though fierce and, according to the Romans, ignorant, were possessed of an intelligence of a very high order. The Romans were again matched, and they settled down to trade, and their wits were sharpened. They early set to work to build the equivalent of the modern bungalow, with the latest floors consisting of tessellated pavements, and heated by dry hot-air apparatus. It was not in those days a question, as at present in the tropics, of wide verandahs; it was a question of warmth and luxury, houses with heating apparatus and tessellated floors, the remains of which are still to be found, wherever the Romans went. They also constructed substantial roads, brought to their towns and houses water-supplies either in lead pipes, as at Chester, or in aqueducts, as in Spain, France, and many other places.

Central America suited the Conquistadores, the climatic conditions were not too rigorous, tradition and environment were fairly favourable. The health conditions, it is true, were hostile, but they made up their minds to live with the people and to settle. The Romans found in England the climatic and health conditions favourable, and a warlike people with old-standing traditions and an environment generally suitable, and, above all, intelligence, and this fact alone stimulated them and made them settle in earnest. 
That they did settle and improve our country is well known to all. When England colonized India the English were met by a country possessing unique monuments of art, religion and literature. Again, its people were highly civilized and skilled, and their traditions were, if anything, older than those of the British. It is true that the climatic conditions were very severe, but, no doubt, the invaders argued that if 44 millions of people had developed such a high degree of civilization in the past under those conditions, surely they, the British, could do likewise; and the invaders set to work to civilize and to colonize in the spirit of the Romans. They built substantial bungalows, developed cities, made roads, and settled down in earnest to improve matters and to trade in the right spirit. To commence with, the invaders formed themselves into a well organized body-the old East India Company. As this body was endowed with traditions and fair business principles, prepared to do business on equitable terms and to sell articles for a fair value and not at fancy prices, this in itself was enormous gain.

When in later years the French colonized Africa ther met with an intelligent Muhammadan people with old traditions and an environment more like their own, and they set to work to construct harbours, to remodel towns, make roads, and generally to open up the country just as Cæasar had done in France. The health conditions were fairly good.

Later, when we took possession of Egypt, we found ourselves in a country teeming with tradition, and with a highly intelligent people: we set to work to construct towns, to develop the land, and to establish banks. Health and climatic conditions were fairly favourable, environment and tradition certainly were.

In India the climatic conditions were exceedingly hostile to colonization; in Egypt they were better; in South Africen Australia, New Zealand, and in Central America, we no doubt gained a foot-hold, because the climatic conditions were more favourable. In West Africa the contrast is very striking. The earliest records show that West Africa has generally been regarded as the "black spot of the world"the spot where the lowest races of mankind had. their home. 
From the earliest times it was fixed upon as the spot where lowly organized human beings were developed, to become the slaves of the white man in every part of the world.

It is true that the climatic and health conditions of West Africa are very bad, but they are no worse than those of India, Louisiana, or Central America. Indeed, I have experienced a more stifling, damp heat in New Orleans in June, viz., $104^{\circ} \mathrm{F}$., than I have in .West Africa or in Central America ; but the Louisiana trader set to work to build modern New Orleans, and in spite of climatic and health disadvantages, he constructed the wide streets and modern bungalows to be found there, and contrived, generally, to live a civilized life. So also in India the invader set to work to build houses on a plan to which he was accustomed and to found cities.

In West Africa, therefore, not only the climatic conditions, but the health conditions also, are bad. It is true that they were bad in India and in New Orleans, Central America and the West Indies, but the natives there were more intelligent, and the invaders set to work to improve the conditions, the result being such magnificent cities as Rio, Santos, and Panama. Unlike India, West Africa was invaded by a very poor class of trader, quite devoid of the traditions of the old East India Company, some of them, in fact, being descended from slave traders. The invaders found themselves face to face with a comparatively ignorant race, in fact, a veritable pack of children; they found they could gather shells on the East Coast of Africa, and sell them as coinage on the West Coast. Indeed, there was no trickery in trade that was not practised upon these poor black children of Africa. From cowries we might go on to stair-rods, bits of brass, manillas, "trader's gin," "gold water," obsolete guns-all these were substitutes for legitimate business. These frauds could not have been practised in India, nor in England when the Romans were here, but the African commercial exploiter was face to face with a more simple-minded race, and he took a mean advantage of his position with the native black, who, in his simplicity and ignorance, did not grumble at the treatment. How different in Indip - ad England. This shews to my mind, not only that climatic ana iealth conditions 
are far from insuperable, but that it is a question also of environment and intelligence. Given an intelligent population, the invaders have to smarten themselves, as witness the colonization of the world. Given a set of children, the invaders have every inducement to take advantage of them, and are liable to become degenerate in consequence. In Africa there is little religious tradition, little art, and little business capacity, as we understand it in Europe. There is in consequence hardly any mental bond between the invader and the invaded, and the country is given up to traders. In this connection I would like to point out that the Church for centuries has tried to elevate the primitive intelligence; while the military men have attempted to drill and organize the black forces, and the doctors have endeavoured to direct the primitive practice of medicine into better paths. These three forces are at work trying to improve the primitive native condition; and, likewise, the traders, when face to face with an intelligent people, should try to assist their evolution from the primitive into a more highly organized state. But, unfortunately, when the natives are very primitive, the merchant tends to take advantage of the ignorance of the natives. This, I venture to say, is at the root of our failure to settle in West Africa.

Had we had better pioneer merchants in Africa, Lagos and Freetown would have been very different from what they are to-day.

When an endeavour was made a few years ago to substitute banks for cowries, stair-rods, \&c., the man who endeavoured to do so was met by the opposition of the vested interests.

Science has clearly pointed out what may be done in the direction of health preservation. Recognising to the full in the first place the position of the black inhabitants as regards endemic disease, the white men must reside in their own quarters, just as in Morocco the various sects are to be found each in its respective quarter. There is no disregard of the black man in this: white people must live in their own houses, and these houses can be built on their own models, just as the Romans did in Chester in the old days. We know precisely how to avoid malaria, yellow fever, and other deadly diseases; we know how to ventilate our houses, and we can 
obtain very good food if we only take a little care; we can grow many vegetables; and we can introduce many sports just as the Romans did; we can, in fact, carry out the plan described by Major Giles in his pamphlet entitled "General Sanitation and Anti-Malarial Measures in Sekondi, the Goldfields, and Kumassie, and a comparison between the conditions of European Residence in India."

I think I have demonstrated from past and present examples all over the world that it is possible to colonize every part of the globe, that the obstacles created by climatic and health conditions are not insuperable, and that questions of environment and tradition can be solved if, like the true Missionary of old, we were to settle down in earnest to study the people and try to elevate them.

Then, and only then, shall we Britishers begin to take root and multiply and be able to rear our children in West Africa.

It can be done, it has been done, and the twentieth-century man ought not to be beaten.

RUBERT BOYcE. 